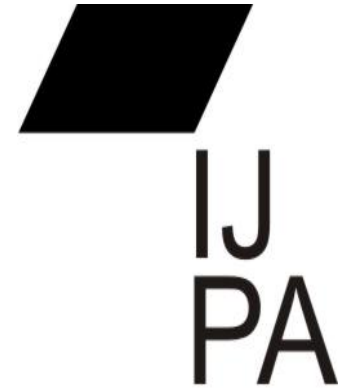

ISSN $2460-0369$

\section{IMPLEMENTASI KEBIJAKAN DANA DESA}

\author{
Khuswatun Chasanah, Slamet Rosyadi, Denok Kurniasih
}

\author{
Program Pascasarjana Ilmu Administrasi \\ Universitas Jenderal Soedirman \\ khuswatun70@gmail.com
}

\begin{abstract}
The indicator of performance appraisal of policy implementation must notice some aspects, which are: access, refraction, accuracy of the service, accountability, and suitability of the program with the needs. Gumelem Kulon Village, in these first two years, reaches the biggest Village Fund among the others 266 villages, and it become one of the examples of the geographic condition of Banjarnegara Regency. The purpose of this research is to describe and analyze the implementation of Village Fund in Gumelem Kulon Village, in Banjarnegara Regency. This research uses qualitative method, with purposive sampling technique. The result of this research shows that the implementation of Village Fund in Gumelem Kulon Village hasn't runs optimally. Some aspects that haven't fulfilled optimally are: First, the socialization in these two years still using verbal method, so the program hasn't socialized optimally. Second, there is refraction or deviation in implementation, which is $100 \%$ of Village Fund allocated to physical development so there's no allocation for human empowerment. Third, the researcher found that most of the people in Gumelem Kulon thought that physical development is more important than empowerment. There are also some success achievements in implementation of the policy. First, there's a local tradition called songolasan which is success to increase the people's participation in implementation of Village Fund. But, songolasan as a local tradition hasn't been able to reach ideal participation. That's because songolasan is an informal media, meanwhile the proposal that can be applied with Village Fund is the proposal through the formal procedure. Second, the development activity is match with the development plan. Third, the Gumelem Kulon Village's government has showed their responsible horizontally to the BPD (Badan Permusyawaratan Desa or Village Consultative Agency) as the representation of the people, and vertically to the regent through the district.
\end{abstract}

Keywords: Policy implementation, Village Fund, access, deviations, service accuracy, accountability, programs and needs 
Abstrak: Indikator penilaian kinerja implementasi kebijakan memperhatikan beberapa aspek antara lain akses, bias, ketepatan layanan, akuntabilitas dan kesesuaian program dengan kebutuhan. Desa Gumelem Kulon pada dua tahun pertama menjadi yang terbesar dari 266 desa lainnya di Kabupaten Banjarnegara dalam penerimaan dana desa (DD) dan merupakan salah satu desa yang dapat menggambarkan kondisi geografis secara umum Kabupaten Banjarnegara. Penelitian ini bertujuan untuk mendeskripsikan dan menganalisis implementasi kebijakan dana desa di Desa Gumelem Kulon Kabupaten Banjarnegara. Metode penelitian yang digunakan adalah metode kualitatif, dengan teknik pemilihan informan purposive sampling. Hasil penelitian ini yaitu Implementasi Dana Desa di Kabupaten Banjarnegara Studi Penggunaan DD di Desa Gumelem Kulon belum berjalan secara optimal. Beberapa aspek yang belum terpenuhi secara optimal diantaranya: pertama, dari sisi Aspek akses, sosialisasi yang dilakukan pada dua tahun pertama masih dengan metode lisan dan belum tersampaikan secara maksimal. Kedua, terjadi bias atau penyimpangan yaitu seluruh pemakaian DD $100 \%$ digunakan untuk pembanguna fisik, belum mengarah kepada pemberdayaan masyarakat. Ketiga, peneliti menemukan bahwa masyarakat Desa Gumelem Kulon sebagian besar masih berpendapat bahwa pembangunan fisik lebih penting dari pada pemberdayaan. Merujuk pada pembahasan hasil penelitian, beberapa aspek yang menunjukan keberhasilan implementasi kebijakan diantaranya yaitu: Pertama, ada tradisi lokal songolasan yang mampu untuk meningkatkan partisipasi masyarakat dalam pelaksanaan dana desa. Namun songolasan sebagai media lokal ternyata belum mampu mengantarkan pada partisipasi ideal. Hal tersebut disebabkan karena songolasan adalah media informal, sedangkan usulan yang bisa dilaksanakan dengan anggaran dana desa adalah usulan yang melaui prosedur musyawarah berjenjang secara formal. Kedua, kegiatan pembangunan yang direalisasikan sesuai dengan kegiatan yang direncanakan. Ketiga, pemerintah Desa Gumelem Kulon sudah melaksanakan pertanggungjawaban secara horisontal kepada BPD sebagai wakil dari masyarakat dan pertanggung jawaban secara vertikal kepada bupati melaui camat.

Kata kunci: Implementasi kebijakan, dana desa, akses, penyimpangan, ketepatan layanan, akuntabilitas, program dan kebutuhan. 


\section{PENDAHULUAN}

Penetapan Undang-Undang (UU) Nomor 6 Tahun 2014 Tentang Desa memperkuat posisi Desa dalam kerangka Negara Kesatuan Republik Indonesia. Penetapan undang-undang tersebut memperjelas tugas, peran dan fungsi desa dalam mengelola desa, menjalankan pemerintahan desa, dan memberikan pelayanan bagi masyarakatnya guna tercapainya cita-cita bersama mewujudkan kesejahteraan masyarakat. Penetapan UU Nomor 6 Tahun 2014 mempertegas bahwa pemerintah desa dalam mengatur desa tidak akan terlepas dari tujuan pengaturan desa dan menjadikannya dasar dalam melaksanakan pembangunan desa.

Salah satu kebijakan yang mengiringi penetapan UU Nomor 6 Tahun 2014 adalah kebijakan Dana Desa. Dana Desa, sebagaimana dijelaskan dalam Peraturan Pemerintah Nomor 60 Tahun 2014 tentang Dana Desa yang bersumber dari APBN, adalah dana yang bersumber dari Anggaran Pendapatan dan Belanja Negara (APBN) yang diperuntukkan bagi Desa yang ditransfer melalui Anggaran Pendapatan dan Belanja Daerah (APBD) Kabupaten/Kota dan digunakan untuk membiayai penyelenggaraan pemerintahan, pelaksanaan pembangunan, pembinaan kemasyarakatan, dan pemberdayaan masyarakat. Tujuan dari Dana Desa pada dasarnya adalah mewujudkan pertumbuhan ekonomi yang inklusif dengan lebih memeratakan pendapatan. Melalui Dana Desa yang jumlahnya mencapai milyara rupiah, memungkinkan desa melaksanakan berbagai program dan kegiatan pembangunan desa untuk mewujudkan kesejahteraan masyarakat.

Menindaklanjuti kebijakan tentang Desa dan Dana Desa, Kabupaten Banjarnegara menerbitkan Peraturan Bupati Nomor 26 Tahun 2015 tentang Tata Cara Pembagian dan Penetapan Besaran Dana Desa. Kebijakan tentang dana desa di tingkat kabupaten ini, menyebutkan bahwa prioritas penggunaan dana desa adalah untuk pembangunan dan pemberdayaan. Sebagai implementor kebijakan adalah pemerintah desa dengan sasaran kebijakannya adalah masyarakat desa.

Desa Gumelem Kulon memperoleh Dana Desa yang paling besar seKabupaten Banjarnegara selama dua tahun pertama, dan merupakan penerima terbesar selama tiga tahun pelaksanaan Dana Desa dalam lingkup kecamatan. 
Lebih rinci mengenai besaran Dana Desa yang diterima tiap desa di Kecamatan Susukan bisa dilihat di tabel berikut.

Tabel 1. Pagu Indikatif Dana Desa Tahun 2016-2017 di Kecamatan Susukan

\begin{tabular}{llccc}
\hline \multirow{2}{*}{ No } & \multicolumn{1}{c}{$\begin{array}{c}\text { Nama } \\
\text { Desa }\end{array}$} & $\begin{array}{c}\text { Dana Desa } \\
2015\end{array}$ & $\begin{array}{c}\text { Dana Desa } \\
2016\end{array}$ & $\begin{array}{c}\text { Dana Desa } \\
2017\end{array}$ \\
\hline 1 & Berta & 282.758 .000 & 632.094 .000 & 808.475 .000 \\
2 & Derik & 287.846 .000 & 643.557 .000 & 820.788 .000 \\
3 & Karangjati & 278.587 .000 & 642.322 .000 & 812.804 .000 \\
4 & Gumelem Wetan & 328.436 .000 & 631.926 .000 & 918.943 .000 \\
5 & Gumelem Kulon & 340.297 .000 & 728.241 .000 & 930.167 .000 \\
6 & Panerusan Wetan & 278.920 .000 & 631.926 .000 & 805.727 .000 \\
7 & Penerusan Kulon & 276.250 .000 & 627.225 .000 & 798.605 .000 \\
8 & Brengkok & 270.630 .000 & 614.873 .000 & 790352.000 \\
9 & Pakikiran & 274.280 .000 & 602.431 .000 & 781.462 .000 \\
10 & Piasa Wetan & 267.482 .000 & 629.797 .000 & 766.301 .000 \\
11 & Karangsalam & 276.006 .000 & 629.797 .000 & 792.795 .000 \\
12 & Kemranggon & 278.287 .000 & 636.285 .000 & 808.874 .000 \\
13 & Dermasari & 275.924 .000 & 631.260 .000 & 802.919 .000 \\
14 & Kedawung & 279.530 .000 & 632.720 .000 & 810.268 .000 \\
15 & Susukan & 273.556 .000 & 629.972 .000 & 801.138 .000 \\
\hline
\end{tabular}

Sumber: Kasi Pemberdayaan Masyarakat Desa Kecamatan Susukan 2017

Besarnya Dana Desa yang diterima oleh Desa Gumelem Kulon berpotensi strategis dalam mendukung pembangunan desa. Hal tersebut setidaknya tampak, jika berkaca dari hasil penelitian mengenai Alokasi Dana Desa (ADD), yang merupakan kewajiban Pemerintah Kabupaten/Kota untuk mengalokasikan anggaran untuk Desa yang diambilkan dari Dana Bagi Hasil (DBH) dan Dana Alokasi Umum (DAU) yang merupakan bagian Dana Perimbangan. Penelitian Sukesi (2007) menyimpulkan bahwa penggunaan Alokasi Dana Desa (ADD) dapat membiayai program pemerintah desa dan efektif meningkatkan ekonomi pedesaan. Sehubungan dengan hal tersebut, menarik untuk dikaji "Bagaimanakah implementasi kebijakan Dana Desa di Desa Gumelem Kulon Kabupaten Banjarnegara?”. Tujuan dari penelitian ini yaitu untuk mendeskripsikan dan menganalisis implementasi kebijakan Dana Desa di Desa Gumelem Kulon Kecamatan Susukan Kabupaten Banjarnegara

\section{TINJAUAN PUSTAKA}

Implementasi merupakan tahap realisasi tujuan-tujuan program. Dalam hal ini yang perlu diperhatikan adalah persiapan implementasi, yaitu memikirkan dan memperhitungkan secara matang berbagai kemungkinan keberhasilan dan kegagalan termasuk hambatan atau peluang-peluang yang ada 
dan kemampuan organisasi yang diserahi tugas melaksanakan program (Mulyadi, 2015:25). Menurut Pressman dan Wildavsky impementasi dimaknai dengan beberapa kata kunci sebagai berikut: untuk menjalankan kebijakan (to carry out), untuk memenuhi janji-janji sebagaimana dinyatakan dalam dokumen kebijakan (to fullfill), untuk menghasilkan output sebagaimana dinyatakan dalam tujuan kebijakan (to produce), untuk mneyelesaikan misi yang harus diwujudkan dalam tujuan kebijakan (Purwanto, 2015:20)

Terbitnya Undang-Undang Nomor 6 Tahun 2014 tentang Desa (UU Desa) telah membuka sebuah era baru dalam pembangunan desa di Indonesia. Dana desa yang jumlahnya cukup besar memberikan peluang percepatan pembangunan desa dan meningkatkan kesejahteraan masyarakat desa. Desa yang selama ini menjadi objek kebijakan dan pelaksanaan pembangunan, kini menjadi subyek pembangunan dengan kewenangan dan kesempatan yang lebih luas dalam merumuskan kebijakan dan melaksanakan pembangunannya sendiri.

Implementasi kebijakan publik yang dimaksud dalam penelitian ini adalah implementasi kebijakan dana desa yang tertuang dalam UU Desa. Kebijakan Di tingkat kabupaten, Banjarnegara berkaitan dengan adanya sebagai tindak lanjut UU Desa dan PP No.60 Tentang Dana Desa diterbitkan Peraturan Bupati Banjarnegara Nomor 26 Tahun 2015 tentang Tata Cara Pembagian dan Penetapan Besaran Dana Desa, di mana di dalamnya dijelaskan mengenai dana desa yaitu:

"Dana desa adalah dana yang bersumber dari Anggaran Pendapatan dan Belanja Negara yang diperuntukkan bagi desa yang ditransfer melalui Anggaran Pendapatan dan Belanja Daerah dan digunakan untuk membiayai pelaksanaan pembangunan dan pemberdayaan masyarakat"

Sebagai implementor kebijakan adalah pemerintah desa dengan sasaran kebijakannya adalah masyarakat desa dan dengan tujuan jangka pendek yang akan diteliti yaitu peningkatan infrastruktur pedesaan serta peningkatan pendapatan masyarakat desa.

Menurut Purwanto (2015:106-110), ada berbagai indikator yang dapat digunakan untuk melihat kinerja implementasi kebijakan: 


\section{Akses}

Akses mengandung pengertian terjadinya kesamaan kesempatan bagi semua kelompok sasaran, apapun karakteristik individual maupun kelompok yang melekat pada dirinya, seperti gender, etnisitas, agama dan afiliasi politik. Akses juga bearti tidak terjadinya diskriminasi untuk terlibat dan menikmati manfaat kebijakan atau program karena karakteristik yang melekat pada individu atau kelompok.

2. Bias

Bias merupakan indikator yang digunakan untuk menilai apakah pelayanan yang diberikan oleh implementer bias (menyimpang) kepada kelompok masyarakat yang bukan menjadi sasaran untuk menikmati bantuan atau pelayanan yang diberikan oleh pemerintah melalui suatu kebijakan atau program.

3. Ketepatan layanan

indikator ini digunakan untuk menilai apakah pelayanan yang diberikan dalam implementasi suatu program dilakukan tepat waktu atau tidak.

4. Akuntabilitas

Indikator ini digunakan untuk menilai apakah tindakan para implementer dalam menjalankan tugas mereka untuk menyampaikan keluar kebijakan kepada kelompok sasaran dapat dipertanggung jawabkan atau tidak.

5. kesesuaian program dan kebutuhan.

Indikator ini digunakan untuk mengukur apakah berbagai keluaran kebijakan atau program yang diterima oleh kelompok sasaran memang sesuai dengan kebutuhan mereka atau tidak.

Dana Desa adalah dana yang bersumber dari Anggaran Pendapatan dan Belanja Negara (APBN) yang diperuntukkan bagi desa dan desa adat yang ditransfer melalui Anggaran Pendapatan dan Belanja Daerah (APBD) kabupaten/kota dan digunakan untuk membiayai penyelenggaran pemerintahan, pembangunan, serta pemberdayaan masyarakat, dan pembinaan masyarakat. 
Regulasi yang mengatur penggunaan dana desa diprioritaskan untuk pembangunan dan pemberdayaan masyarakat.

Dana Desa sebagai salah satu sumber pendapatan desa mempunyai peran strategis dalam mendukung pembangunan desa. Beberapa penelitian terdahulu antara lain; Sukesi (2007) menyimpulkan hal demikian yaitu penggunaan Alokasi Dana Desa (ADD) dapat membiayai program pemerintah desa dan efektif meningkatkan ekonomi pedesaan. Tidak hanya pada aspek ekonomi, ADD juga berperan dalam pembangunan fisik desa seperti dalam penelitian Rosyadi dkk (2008) dan Mahfudz (2009). Karenanya diperlukan manejemen yang handal, agar ADD dapat bermanfaat untuk kesejahteraan masyarakat desa. Rosyadi dkk (2008) menemukan bahwa dalam pengelolaan ADD ditemukan beberapa masalah seperti keterlambatan dana, keterlambatan realisasi rencana, dan penyesuaian aspek teknis, temuan lainnya adalah implementasi ADD sudah sesuai prosedur.

Melalui manajemen yang baik maka implementasi ADD juga aka mengarah pada tujuan yang telah ditetapkan. Manajemen yang matang juga akan mengeleminir kegagalan dalam implementasi ADD seperti yang dilaporkan oleh Israwan (2011) dalam penelitiannya yang menemukan bahwa pengelolaan ADD belum berhasil sebagai akibat sistem dan mekanisme pelaporan keuangan yang telah disusun oleh pemerintah kabupaten ternyata tidak dapat dilaksanakan dengan baik oleh pemerintah desa.

Penelitian Wisakti (2008) terkait dengan ADD diketahui implementasi kebijakan ADD di Kecamatan Geyer Kabupaten Grobogan berjalan cukup lancar. Namun demikian apabila dikaitkan dengan pencapaian tujuan, pelaksanaan ADD di Kecamatan Geyer Kabupaten Grobogan belum optimal, yaitu tujuan adanya peningkatan kemampuan lembaga kemasyarakatan di desa dalam perencanaan, pelaksanaan dan pengendalian pembangunan belum berjalan secara optimal.

\section{METODE PENELITIAN}

Penelitian ini menggunakan metode penelitian kualitatif. Metode penelitian kualitatif bermaksud untuk memahami fenomena yang dialami oleh subjek penelitian, dengan cara mendeskripsikannya dalam bentuk kata-kata dan bahasa, pada suatu konteks tertentu bersifat alamiah dan dengan memanfaatkan 
berbagai metode alamiah (Moleong, 2015:6). Teknik pemilihan informan menggunakan teknik purposive sampling yaitu pemilihan informan dengan pertimbangan tertentu. Dengan menggunakan teknik sampling tersebut, ditetapkan informan yang terdiri dari Pemerintah Desa Gumelem Kulon yang meliputi kepala desa sebagai kuasa pengguna anggaran dan sekretaris desa sebagai koordinator program, anggota Badan Permusyawaratan Desa (BPD), masyarakat dan pendamping desa yang bertugas di wilayah Kecamatan Susukan. Penelitian ini dilaksanakan dua bulan yaitu mulai bulan Mei sampai dengan Juni 2017 dengan mengambil lokasi di Desa Gumelem Kulon Kecamatan Susukan Kabupaten Banjarnegara. Metode analisis data menggunakan odel analisis interaktif (lihat Miles, Huberman, dan Saldana, 2014). Untuk mewujudkan keabsahan data, digunakan teknik triangulasi, baik menggunakan triangulasi sumber, metode, maupun data.

\section{PEMBAHASAN}

\section{Akses}

Hasil penelitian terkait dengan informasi DD dan penyebarannya kepada masyarakat, menunjukkan bahwa penyebarluasan informasi DD menggunakan beberapa media. Pertama, penyebarluasan informasi DD melalui forum resmi di tingkat desa. Penyebarluasan informasi DD melalui forum resmi ini dilaksanakan oleh kepala desa, aparat desa, serta ketua dan anggota BPD. Kedua, penyebarluasan informasi DD melalui forum tidak resmi namun terjadwal secara periodik di tingkat desa. Songolasan merupakan forum tidak resmi yang dimaksud. Songolasan merupakan tradisi Desa Gumelem Kulon yang dilaksanakan setiap tanggal 19 bertempat di balai desa. Songolasan bertujuan untuk menyebarluaskan informasi dan menjaring aspirasi masyarakat. Ketiga, penyebarluasan informasi DD melalui forum tidak resmi dan tidak terjadwal di tingkat desa. Forum jenis ketiga ini berbentuk majelis pengajian masyarakat, yang selain menjadi media siraman rohani, juga menjadi media penyampaian informasi desa, tidak terkecuali kebijakan DD serta program-program pembangunan desa yang dibiayai melalui DD. Keempat, penyebarluasan informasi melalui papan informasi kegiatan. 
Media informasi yang pertama hingga ketiga merupakan media yang bersifat terbuka, memungkinkan proses dialogis atau komunikasi 2 arah. Sementara, media yang keempat lebih bersifat satu arah, serta hanya menyampaikan informasi yang lebih terbatas.

Uraian proses penyebaran informasi DD beserta program-program pembangunan desa yang dibiayainya melalui media-media formal maupun informal di tingkat desa menunjukkan bahwa akses masyarakat desa untuk memperoleh informasi mengenai DD maupun program-program pembangunan desa yang dibiayai dengan DD menjadi lebih terbuka. Hal tersebut tampak pada pengetahuan masyarakat akan DD, usulan-sulan program pembangunan yang disampaikan masyarakat kepada pemerintah desa, serta kehadiran perwakilan masyarakat dalam proses perencanaan pembangunan desa, termasuk perencanaan program pembangunan desa yang akan dibiayai dengan DD. Kehadiran masyarakat tersebut tampak pada musrenbangdes yang dihadiri oleh 57 orang laki-laki dan 11 orang perempuan. Apabila dirinci, perwakilan kelompok masyarakat tersebut terdiri dari anggota PKK (11 orang), LP3M (2 orang), BPD (8 orang), perangkat desa (6 orang), serta delegasi dusun (39 orang). Meski demikian, realitas empiris di lokasi penelitian menunjukkan bahwa usulan-usulan pembangunan desa sebagai implikasi terbukanya akses informasi, masih terkendala dalam proses musrenbang di mana usulan-usulan masyarakat tidak bisa diterima karena tidak termasuk dalam RPJM Desa Gumelem Kulon.

Pemanfaatan media-media di atas, tidak terkecuali songolasan yang pada akhirnya mampu membuka akses masyarakat terhadap informasi DD hingga memungkinkan masyarakat mengusulkan program-program pembangunan. Temuan-temuan penelitian ini selaras dengan hasil penelitian Kurrohman (2015), bahwa masyarakat desa di Kabupaten Banyuwangi mempunyai pola tersendiri untuk dapat meningkatkan partisipasi dan menyerap aspirasi dengan budaya lokal yang dinamai “tilik Dusun". Temuan penelitian ini pun sejalan dengan hasil penelitian Mahmud (2007) yang menyatakan dalam komunikasi pembangunan, forum jamaah, jamiyah/majlis taklim, pengajian umum dan forum pertemuan $160 \mathrm{RT} / \mathrm{RW}$ telah terbukti 
menjadi ajang pertemuan yang utama bagi elemen masyarakat dalam membahas berbagai persoalan yang terkait dengan sarana prasarana. Sebagai forum yang sangat akrab dan menyatu dengan aktivitas keseharian masyarakat (community friendly), maka institusi-institusi lokal tersebut terbukti lebih fleksibel terhadap penerapan prinsip-prinsip keikutsertaan, keterbukaan, rutinitas dan kohesivitas.

Kesesuaian penelitian ini dengan 2 penelitian sebelumnya, pada akhirnya mendukung tesis Purwanto (2015) bahwa melalui media formal maupun informal, pada akhirnya membuka akses masyarakat terhadap informasi DD. Kesamaa akses juga berlaku bagi semua kelompok sasaran, apapun karakteristik individual maupun kelompok yang melekat pada dirinya, seperti gender, etnisitas, agama dan afiliasi politik. Akses juga berarti tidak terjadinya diskriminasi untuk terlibat dan menikmati manfaat kebijakan atau program karena karakteristik yang melekat pada individu atau kelompok.

Berdasarkan temuan-temuan dan pembahasan di atas dapat disusun proposisi sebagai berikut.

Akses masyarakat terhadap informasi dana desa dan program pembangunan lebih terbuka melalui media formal dan informal desa. Songolasan sebagai media informal periodik membuka akses untuk memperoleh informasi kebijakan serta mengusulkan program-program pembangunan, meski kemudian terhambat kebijakan perencanaan pembangunan desa lainnya. Sekalipun demikian, akses masyarakat yang terbuka melalui media formal dan informal desa mampu mendukung implementasi kebijakan Dana Desa.

\section{Penyimpangan (Bias)}

Deskripsi pelaksanaan program-program pembangunan desa yang dibiayai melalui DD menunjukkan bahwa program-program pembangunan desa tersebut lebih mengarah pada pembangunan fisik. Pilihan pembangunan yang bersifat fisik tersebut, tidak terlepas dari kondisi serta kebutuhan masyarakat Desa Gumelem Kulon. 
Apabila dikaji dari sisi proses perencanaan pembangunan desa, pilihan ke arah pembangunan fisik telah sesuai dengan proses dan tahapan perencanaan pembangunan Desa Gumelem Kulon. Artinya, pilihan ke arah pembangunan fisik tersebut telah melalui tahapan perencanaan dari tingkat RT hingga desa, serta memperoleh ranking kebutuhan masyarakat tertinggi berdasarkan kriteria kebutuhan yang telah disusun pemerintah Desa Gumelem Kulon. Dengan demikian, tidak ada bias terhadap proses dan tahapan perencanaan pembangunan desa.

Fakta dan data penelitian selanjutnya, menuntun pada makna sebagian besar masyarakat Desa Gumelem Kulon masih berpandangan pembangunan fisik lebih penting dibandingkan dengan pemberdayaan. Oleh karena itulah pembangunan fisik menjadi pilihan usulan program-program pembanguan dalam musyawarah pembangunan desa mulai dari tingkat RT hingga desa. Pilihan pembangunan fisik desa tersebut juga tidak bisa dilepaskan dari kondisi geografis dan infrastruktur desa yang kurang memadai.

Pilihan strategi pembangunan desa pada pembangunan fisik menarik bila dibandingkan dengan perspektif pembangunan dari Nugroho. Nugroho (2007:4344) menjelaskan, pembangunan adalah proses natural mewujudkan cita-cita bernegara yaitu terwujudnya masyarakat makmur sejahtera secara adil dan merata. Kesejahteraan ditandai dengan kemakmuran yaitu, meningkatnya konsumsi yang disebabkan oleh meningkatnya pendapatan. Salah satu pertanyaan dasar yang perlu dijawab pembangunan perlu diletakan pada arah pemberdayaan masyarakat untuk menuntaskan masalah kesenjangan berupa pengangguran, kemiskinan dan ketidakmerataan dengan memberikan ruang dan kesempatan yang lebih besar kepada rakyat banyak untuk berpartisipasi secara aktif dalam pembangunan.

Pilihan ke arah pembangunan fisik Desa Gumelem Kulon telah memenuhi kebutuhan infrastruktur fisik desa. Meski demikian, jika dilihat dari tujuan substantif pembangunan yakni maujudnya kesejahteraan masyarakat, pilihan pembangunan fisik tersebut belum mampu mengarah ke arah tersebut. Hal tersebut tampak pada data kemiskinan desa, sebagaimana diuraikan dalam bab 1 di muka. 
Uraian di atas menunjukkan, bahwa kesejahteraan masyarakat tidak mungkin dapat terwujud tanpa melalui proses pemberdayaan. Pembangunan fisik yang tidak disertai dengan pemberdayaan akan berimplikasi pada upaya peningkatan pendapatan dan kesejahteraan masyarakat serta sustainabilitas pembangunan beserta hasil-hasilnya. Oleh karenanya, pembangunan fisik harus disinergikan dengan progam pemberdayaan masyarakat. Sebagai contoh dalam hal meningkatkan kemampuan perencanaan, pengelolaan dan pengawasan. Kemampuan tersebut harus terus diupayakan, karena kemandirian tidaklah muncul begitu saja namun merupakan hasil dari program pemberdayaan masyarakat. Idealnya pembangunan fisik harus tetap diiringi dengan peningkatan kapasitas masyarakat menuju masyarakat mandiri.

Uraian di atas menunjukkan, meski tidak ada bias terhadap proses dan tahapan perencanaan pembangunan desa, namun tampak bias terhadap upaya pemberdayaan masyarakat. Bias merupakan indikator yang digunakan untuk menilai apakah pelayanan yang diberikan oleh implementor, bias (menyimpang) kepada kelompok bukan sasaran dan penyimpangan kegiatan dari perencanaan (Purwanto, 2015:106-110). Program dan kegiatan yang telah dilaksanakan belum sepenuhnya berpedoman pada pasal 19 PP No. 60 Tahun 2014 tentang Dana Desa yang Bersumber dari APBN serta pasal 4 Peraturan Menteri Desa, Pembangunan Daerah Tertinggal dan Transmigrasi No 22 tahun 2016 Tentang Prioritas Penggunaan Dana Desa Tahun 2017. Kedua kebijakan tersebut yang menyatakan bahwa Dana Desa diprioritaskan untuk membiayai pembangunan dan pemberdayaan masyarakat.

Berdasarkan temuan-temuan dan pembahasan di atas dapat disusun proposisi sebagai berikut:

Pilihan pembangunan fisik desa sebagai akibat dari kondisi geografis desa, tidak bias terhadap proses dan tahapan perencanaan pembangunan desa, namun tampak bias terhadap upaya pemberdayaan masyarakat yang akan berimplikasi pada implementasi kebijakan Dana Desa. 


\section{Ketepatan layanan}

Aspek ketepatan layanan digunakan untuk menilai ketepatan waktu dan kesesuaian anggaran penyelenggaraan pelayanan dalam implementasi suatu program. Hasil penelitian terhadap ketepatan layanan menunjukan ada keterlambatan jadwal penetapan RKP Desa. RKP Desa tahun 2015, jika sesuai regulasi paling lambat selesai pada September 2014, namun baru terealisasi pada maret 2015. Penetapan RKP Desa digunakan sebagai acuan bagi desa dalam menyusun APBDes, sehingga apabila terjadi keterlambatan dalam penetapan RKP Desa akan mempengaruhi waktu penyusunan dan penetapan APBDes. Ketepatan waktu penetapan APBDes menjadi salah satu syarat penyaluran Dana Desa dari kabupaten/kota ke desa.

Hasil penelitian mengenai aspek ketepatan layanan ini, selaras dengan hasil penelitian Rosyadi dkk (2008) yang menyatakan bahwa dalam pengelolaan ADD ditemukan beberapa masalah seperti keterlambatan dana, keterlambatan realisasi rencana, dan penyesuaian aspek teknis. Menurut Purwanto (2005) bahwa suatu program yang memiliki sensitivitas terhadap waktu sangat penting untuk dapat melihat kinerja suatu implementasi, artinya keterlambatan dalam implementasi program akan membawa implikasi kegagalan mencapai tujuan program tersebut.

\section{Akuntabilitas}

Aspek akuntabilitas digunakan untuk menilai pertanggungjawaban para implementor dalam mplementasi kebijakan. Hasil penelitian di Desa Gumelem Kulon menunjukan, Pemerintah Desa Gumelem Kulon telah elaksanakan pertanggungjawaban pengelolaan Dana Desa secara horizontal maupun vertikal. Secara horisontal melaporkan kepada BPD sebagai wakil dari masyarakat, dan secara vertikal melaporkan kepada bupati melalui camat. Kendala akuntabilitas pengelolaan Dana Desa tampak pada Struktur Organisasi dan Tata Kerja (SOTK) yang belum terpenuhi dari sisi sumber daya manusianya, serta kemampuan penggunaan teknologi informasi yg belum maksimal. Kendala lain, disebabkan belum ada petunjuk teknis tentang adminitrasi dan pelaporan pengelolaan Dana Desa pada 2 tahun pertama pelaksanaan kebijakan Dana Desa sehingga diperlukan pendampingan bagi para implementor di tingkat desa. 
Faktor yang memperlancar proses akuntabilitas adalah pengalamaan dan pendidikan para pengelola yang memadai. Selain itu, komunikasi dan koordinasi yang baik dengan kepala desa memberikan kemudahan pemahaman terhadap teknis administrasi dan pelaporan.

Kapasitas sumber daya manusia (SDM) yang handal bisa diperoleh dari tingkat pendidikan formal dan pengalaman dalam mengelola kegiatan sebelumnya. Tingkat pendidikan dan pengalaman tersebut sangat membantu dalam hal pemahaman peraturan dan kemampuan mengoperasikan teknologi informasi. Peran kepala desa sebagai pimpinan dalam pemerintahan desa sangat strategis untuk memotivasi dan mengkoordinir tim pelaksana kegiatan. Oleh karena itu, kapasitas SDM tim pengelola Dana Desa perlu ditingkatkan agar akuntabilitas implementasi kebijakan semakin baik.

Hasil penelitian ini, sejalan dengan penelitian-penelitian sebelumnya. Penelitian Israwan (2011) tentang pelaksanaan ADD di Kabupaten Purbalingga misalnya, menjelaskan bahwa akuntabilitas administrasi keuangan penggunaan anggaran publik merupakan salah satu upaya untuk mewujudkan akuntabilitas publik dan meningkatkan kepercayaan masyarakat terhadap kinerja pemerintah. Melalui laporan administrasi keuangan ini, publik dapat menilai setiap penggunaan anggaran yang dilakukan oleh pemerintah. Manajemen yang matang juga akan mengeleminir kegagalan dalam implementasi berbagai program pembangunan di perdesaan. Demikian halnya dengan penelitian Agus (2009), yang menyatakan bahwa dari sisi administrasi masih diperlukan adanya pembinaan lebih lanjut, karena belum sepenuhnya sesuai dengan ketentuan.

Uraian tentang aspek akuntabilitas di atas, pada akhirnya selaras dengan tesis Purwanto dan Mardiasmo. Menurut Purwanto (2015) akuntabilitas merupakan salah satu indikator yang untuk menilai apakah tindakan implementor dalam menjalankan tugas dapat dipertanggungjawabkan atau tidak. Akuntabilitas adalah prinsip pertanggungjawaban publik yang berarti bahwa proses penganggaran mulai dari perencanaan, penyusunan dan pelaksanaan harus benarbenar dapat dilaporkan dan dipertanggungjawabkan kepada pemerintah dan masyarakat. Masyarakat tidak hanya memiliki hak untuk mengetahui anggaran 
tersebut tetapi juga berhak untuk menuntut peratnggungjawaban atas rencana ataupun pelaksanaan anggaran tersebut (Mardiasmo, 2002).

\section{Kesesuaian program dan kebutuhan}

Aspek terakhir yang dikaji adalah kesesuaian program dan kebutuhan. Hasil penelitian di Desa Gumelem Kulon menunjukan bahwa implementasi kebijakan Dana Desa telah sesuai dengan kebutuhan masyarakat. Kebutuhan masyarakat tertuang dalam RPJMDes sebagai wujud usulan atau aspirasi warga dalam program pembangunan desa. Realisasi usulan tersebut kemudian dituangkan dalam APBDes sebagai dasar untuk melaksanakan kegiatan sesuai dengan penentuan peringkat masalah per dusun. Pengawasan terhadap implementasi Dana Desa di Desa Gumelem Kulon dilakukan oleh masyarakat melalui BPD dan oleh pemerintah kabupaten melalui camat.

Implementasi kebijakan Dana Desa di Desa Gumelem Kulon selama 3 tahun berjalan relatif lancar dan tidak ada temuan yang bersifat pidana. Kepala desa berperan sebagai kuasa pengguna anggaran, dan mempunyai peran strategis dalam implementasi kebijakan Dana Desa. Kemampuan untuk menggambarkan keadaan masa depan desa yang dipimpinnya akan terlihat pada program-program yang direncanakan dan dilaksanakan. Pendampingan dibutuhkan agar program yang dilaksnakan berjalan sesuai regulasi.

Hasil penelitian mengenai aspek kesesuaian program dan kebutuhan di atas, selaras dengan tesis Purwanto, Handoko, Akib dan Tarigan, serta Terry. Purwanto (2015) menjelaskan, kesesuaian program dengan kebutuhan merupakan salah satu indikator untuk mengukur apakah berbagai kebijakan yang dilakukan atau proram yang diterima masyarakat sesuai dengan kebutuhan mereka atau tidak. Agar pelaksanaan kebijakan berjalan sesuai dengan program dan kebutuhan maka diperlukan fungsi perencanaan dan pengawasan. Menurut Handoko (2001) pengawasan penemuan dan penerapan cara untuk menjamin bahwa rencana telah dilaksanakan sesuai dengan yang telah ditetapkan. Agar suatu program dapat menghasilkan output, maka baiknya program tersebut direncanakan sesuai dengan kebutuhan kelompok sasarannya (Akib dan Tarigan, 2008).

Sedangkan menurut Terry (2006) pengawasan itu menentukan apa yang telah dicapai. Artinya menilai hasil pekerjaan dan apabila perlu untuk 
mengadakan tindakan-tindakan pembetulan sedemikian rupa, sehingga hasil pekerjaan sesuai dengan rencana yang telah ditetapkan sebelumnya.

\section{PENUTUP}

\section{KESIMPULAN}

1. Implementasi Dana Desa di Desa Gumelem Kulon Kabupaten Banjarnegara belum berjalan secara optimal dikarenakan prioritas penggunaan Dana Desa yang seharusnya untuk pembangunan infrastruktur dan pemberdayaan masyarakat, baru fokus terhadap pembangunan infrastruktur saja. Masyarakat masih memandang bahwa kebutuhan utama saat ini adalah pembangunan infrastruktur, yang tercermin pada usulanusulan ketika musrenbang tingkat dusun hingga musrenbang tingkat desa. Desa Gumelem Kulon yang wilayahnya tergolong luas dengan sebagian besar topografinya merupakan perbukitan menyebabkan pembanguan infrastruktur, khususnya jalan dan jembatan menyerap dana yang besar. Secara prosedural penggunaan Dana Desa sudah benar, karena semua program prioritas diputuskan atas kesepakatan dalam musrenbangdes. Pelaksanan Dana Desa dikaji dari aspek akses:

a. Metode sosialisasi dengan lisan yang dipilih oleh pelaksana kegiatan di tahun 2015 dan tahun 2016 Dana Desa belum optimal. Diseminasi informasi melalui lisan masih belum merata dan belum tersampaikan dengan jelas. Diseminasi informasi lebih banyak secara informal sehingga informasi yang diterima tidak utuh dan menimbulkan ketidakpahaman tentang apa dan bagaimana dana desa yang sebenarnya.

b. Akses terhadap keterlibatan masyarakat sudah sesuai dengan regulasi yaitu melibatkan unsur masyarakat antara lain: tokoh agama, tokoh masyarakat, tokoh pendidikan, perwakilan kelompok tani, perwakilan kelompok perajin, perwakilan kelompok perempuan, serta perwakilan kelompok pemerhati dan pelindungan anak.

c. Akses terhadap pemanfaatan sudah sesuai dengan sasaran, karena pelaksanaan pemanfaatan Dana Desa di Desa Gumelem Kulon 
didasarkan pada usulan dari masyarakat. Berawal dari sosialisasi yang ditindaklanjuti dengan rapat di setiap RT, musrenbang tingkat dusun, musrenbang tingkat desa.

2. Pelaksanan Dana Desa dikaji dari aspek penyimpangan

a. Realisasi kegiatan pembangunan sudah sesuai dengan RKP Desa. Hal ini dikarenakan pelaksanaaan kegiatan pembangunan desa selalu mengacu pada RKP Desa, yang penyusunannya dilakukan secara berjenjang, mulai dari tingkat RT, Dusun, dan Desa.

b. Terjadi bias atau penyimpangan yaitu seluruh pemakaian Dana Desa 100\%-digunakan untuk pembanguna fisik, belum mengarah kepada pemberdayaan masyarakat. Semestinya prioritas penggunaan Dana Desa tidak hanya untuk pembangunan fisik, namuan juga untuk pemberdayaan masyarakat sebagaimanaa kebijakan pengelolaan Dana Desa

3. Ketepatan layanan yang berkaitan dengan waktu pelaksanaan Dana Desa belum sesuai. Jadwal pelaksanaan musrenbangdes dan penetapan RKP Desa mengalami kemunduran sehingga menyebabkan mundurnya transfer Dana Desa ke desa, yang pada akhirnya berpengaruh terhadap waktu serta kesesuaian pelaksanaan dengan perencanaan program dan kegiatan pembangunan desa.

Ketepatan layanan yang berkaitan dengan sasaran prioritas program dan ketepatan anggaran sudah sesuai.

4. Pertanggungjawaban secara vertikal dalam bentuk laporan yang disampaikan oleh tim pengelola Dana Desa kepada bupati melalui camat. Pertanggungjawaban secara horizontal kepada warga disampaikan melalui forum resmi yaitu Laporan Pertanggungjawaban Tahunan oleh kepala desa sebagai kuasa pengelolaan Dana Desa kepada Badan Permusyawaran Desa (BPD). Pelaksanaan Dana Desa di Desa Gumelem Kulon, mulai sejak tahun 2015 hingga sekarang, tidak ditemukan penyimpangan yang merupakan tindak pidana.

5. Dari sisi kesesuaian program dengan kebutuhan, pelaksanaan Dana Desa di Desa Gumelem Kulon telah sesuai, yang tampak pada terealisasinya 
kebutuhan masyarakat yang berupa pembangunan infrastruktur desa Luas wilayah dan kondisi topografi Desa Gumelem Kulon menyebabkan penggunaan Dana Desa dari tahun 2015 sampai dengan sekarang masih fokus pada pembangunan insfrastruktur. Namun Demikian, apabila mendasarkan pada regulasi, yakni esensi prioritas pengguanaan Dana Desa yaitu untuk pembanguan dan pemberdayaan masyarakat, belum sepenuhnya terealisasi

\section{SARAN}

1. Penggunaan Dana Desa seyogyanya tidak hanya digunakan untuk pembangunan fisik saja tetapi harus dibarengi dengan program pemberdayaan masyarakat. Program pemberdayaan masyarakat jika berhasil dampaknya bersifat jangka panjang, tidak saja pada saat sekarang tetapi bermanfaat pada masa yang akan datang. Program pemberdayaan masyarakat akan mendukung pelestarian hasil-hasil pembangunan fisik.

2. Metode sosialisasi perlu dikembangkan sehingga tidak hanya mengandalkan metode ceramah atau lisan, namun bisa juga menggunakan media visual yang bisa agar lebih mudah dilihat dan dipahami oleh masyarakat. Pemahaman tersebut diharapkan lebih meningkatkan partisipasi/keterlibatan masyarakat.

3. Desa hendaknya "nguri-uri" (melestarikan) dan memanfaaatkan sumber daya yang berasal dari tradisi lokal agar dapat meningkatkan keterlibatan masyarakat.

4. Penggunaan Dana Desa semestinya dilakukan secara proporsional antara pembangunan fisik dan pemberdayaan masyarakat. Program pemberdayaan tidak harus berdiri sendiri tetapi dapat diintegrasikan dengan program pembanguan infrastruktur. Keterpaduan antara pembanguan fisik dan pemberdayaan adalah upaya cerdas agar pembangunan bersifat partisipatif sehingga kemandirian kemandirian masyarakat sebagaimana tertuang dalam visi Desa Gumelem Kulon, secara bertahap dapat diwujudkan

5. Proses pelaksanaan Dana Desa perlu didukung dengan SDM yang handal, agar beban kerja khususnya administrasi dan pelaporan bisa terbagi secara 
proporsional. Untuk itu, formasi yang masih kosong dalam SOTK, perlu diisi dengan SDM yang handal.

6. Pada masa yang akan datang penggunaan Dana Desa perlu diarahkan untuk pengembangan potensi ekonomi lokal seperti home industry dan destinasi wisata. Perlu dipertimbangkan kerjasama pengembangan destinasi wisata antara Desa Gumelem Kulon dengan Desa Gumelem Wetan,

\section{DAFTAR PUSTAKA}

Agus Subroto. 2009, Akuntabilitas Pengelolaan Dana Desa (Studi Kasus Pengelolaan Alokasi Dana Desa di Desa-desa dalam Wilayah Kecamatan Tlogomulyo Kabupaten Temanggung Tahun 2008), Tesis, Program Pascasarjana Universitas Diponegoro, Semarang.

Akib H, Tarigan A. 2008. Artikulasi Konsep Implementasi Kebijakan: Perspektif, Model dan Kriteria Pengukurannya. Jurnal . 1(8):1-19.

Florence Helen, Roestopo Hartojo Putro (2014). Implementation of the village fund allocation policy (add) to empowering rural communication in cerme village,grogol, kediri. Vol.2 : 134-142.

Mahmud Amir. 2007. Model Komunikasi Pembangunan Dalam Penyediaan prasarana Perdesaan Di Kawasan Pesisir Utara Jawa Tengah (Studi Kasus Desa Morodemak dan Purwosari Kabupaten Demak). Tesis, Program Pascasarjana Universitas Diponegoro, Semarang.

Mardiasmo. 2002. Otonomi dan Manajemen Keuangan Daerah. Yogyakarta: Penerbit ANDI.

Mahfudz, 2009, Analisis Dampak Alokasi Dana Desa terhadap Pemberdayaan Masyarakat dan Kelembagaan Desa, Jurnal Organisasi dan Manajemen, Volume 5, Nomor 1, Maret 2009, 10-22

Milles, Matthew B. And Huberman, A.Michael, dan Saldana, J. 2014. Qualitative Data Analysis, USA:SAGE Publications, Inc.

Moleong, Lexy. 2015. Metodologi Penelitian Kualitatif. PT. Remaja Rosdakarya: Bandung. 
Nugroho Riant dan Wrihatnolo Randy, 2007. Manajemen Pemberdayaan. Sebuah Pengantar dan Panduan Untuk Pemberdayaan Masyarakat. PT. Elex Media Komputindo Kelompok Gramedia. Jakarta

Ompi, Atika Wulan. 2012. “Implementasi Kebijakan Alokasi Dana Desa (ADD)

Dalam Meningkatkan Pembangunan Desa (Studi di Desa Pangu Kec. Ratahan Kab. Minahasa Tenggara)".

Purwanto, erwan agus dan Dyah Ratih Sulistyastuti.2015. Implementasi kebijakan Publik. Konsep dan Aplikasinya di Indonesia. Gava Media. Yogyakarta

Rosyadi, Simin, Bambang T.H., 2008, Problem Implementasi Kebijakan Alokasi Dana Desa, Studi Kasus di Desa Wangon Kecamatan Wangon Kabupaten Banyumas, Swara Politika, Vol. 10 No. 4, hal: 290-297.

Sugiyono, Prof. Dr.. 2010. Metodologi Penelitian Administrasi.:Alfabeta,Bandung Sukesi, 2007. Efektivitas Program Alokasi Dana Desa (ADD) terhadap Perekonomian Desa di Kabupaten Pacitan, Journal Majalah Ilmiah Ekonomi dan Bisnis, Vol. X No. 1 Desember, hal: 43-62.

Terry, G.R. 2006, Prinsip-Prinsip Manajemen, Alih bahasa J.Smith, Bumi Aksara Jakarta, Widarta. 2010.

Kazimoto Plauku (2013) Analysis of village finansial management challenges in arumeru district in tanzania. Vol 3 No.2

Kurrohman Taufik (2015) Accountability of planning on village fund allocation in osing community in Banyuwangi. ICAS, johor Malaysia

Nurcholis, Hanif. Kebijakan Pemerintah Daerah Dalam Pembangunan Desa. Jurnal Desentralisasi, Vol 11 No.2 2013. Hal 401-417

Sugeng, 2014. Faktor-Faktor Yang Mempengaruhi Pengelolaan Keuangan Daerah Dan Implikasinya Terhadap Kinerja Pemerintah Daerah Di Kabupaten Kediri. Jurnal Riset Ekonomi dan Bisnis Vol.1 No2 Juli 2014.

Sutisna, Widya Puspita Ayu. 2013. Partisipasi Masyarakat Dalam Implementasi Kebijakan Masyarakat di Daerah. Jurnal Desentralisasi, Vol 11 No.2. Hal 419-432 
Sutiyo, 2014. Capacity of rural institition in implementating Decentralized Devlopment in Indonesia: case of Three Village in purbalingga District, Central Java province. 